\title{
Genetic Basis of Chronic Hepatitis C Virus and Autoimmune Hepatitis: A Comparative Study
}

\author{
Shalaa AY ${ }^{1}$, Harfoush RA ${ }^{1}$, Ahmed MA², ElKhouly EH ${ }^{3}$ and Morsi MG ${ }^{1 *}$ \\ ${ }^{1}$ Medical Microbiology \&Immunology, Alexandria Faculty of Medicine, Egypt \\ ${ }^{2}$ Clinical Pathology (Hematology), Alexandria Faculty of Medicine, Egypt \\ ${ }^{3}$ Tropical Department, Alexandria Faculty of Medicine, Egypt
}

\begin{abstract}
Background: It is now well established that HCV is of global importance affecting all countries, leading to a major global health problem that requires widespread active interventions for its prevention and control. Chronic hepatitis $\mathrm{C}$ was linked to the development of cirrhosis and Hepatocellular Carcinoma (HCC) in many areas of the world. WHO reported that Egypt has the highest prevalence (22\%) in the world?

Objectives: Susceptibility to infection has been related to immunological disturbances.HCV and autoimmune hepatitis have been associated with HLAA1, A6, A8,-DRB*01-*15 alleles.

Methods: HLA alleles were detected by Sequence Specific Oligoneucleotide Probe (SSOP) using INNO-LiPA based on reverse hybridization after amplification of target HLA allele sequence by Real Time Polymerase Chain Reaction (RT-PCR). The non-organ-specific Antibodies Include Antinuclear (ANA), Smooth Muscle (ASMA), AntiMitochondrial Antibody (AMA), Perinuclear Antineutrophil Cytoplasmic(pANCA), Liver-Kidney Microsomal Antibodies (LK/MA) and Anticardiolipn Antibodies (ACA) were all measured by commercial Indirect ImmunoFluorescence (IF). Clinical significance of these autoantibodies was analyzed in comparison to HCV load by Real Time Polymerase Chain Reaction (RT-PCR) and genotype by 4 byline probe assay INNO-LiPA.

Conclusion: Current understanding of genetic basis (HLA alleles) of chronic HCV genotype 4 cases and autoimmune hepatitis cases free from HCV will aid a lot in treating both types of hepatitis using successful line of therapy as early as possible to save money and side effects of wrong medications.
\end{abstract}

Keywords: HCV genotype 4; HCV viral load; RT-PCR; INNO-LiPA; autoantibodies; IF HLA alleles; SSOP

\section{Introduction}

Hepatitis $\mathrm{C}$ virus is a hepatotropic and lymphotropic virus that has been found to be associated with various diseases and syndromes. Infection with HCV tends to become chronic in most infected individuals, reflecting an inability of the immune system to mount an effective antiviral response [1]. Autoimmune hepatitis is associated with chronic HCV infection [2]. Autoimmune hepatitis is a chronic disease of unknown cause, characterized by continuing hepatocellular inflammation and necrosis and tending to progress to cirrhosis. Immune serum markers frequently are present, autoantibodies against liverspecific and non-liver-specific antigens and increased immunoglobulin $\mathrm{G}(\mathrm{IgG})$ levels [3].

In August 2012, the Centers for Disease Control and Prevention (CDC) expanded their existing, risk-based testing guidelines to recommend a 1-time blood test for Hepatitis C Virus (HCV) infection in baby boomers-the generation born between 1945 and 1965, who account for approximately three fourths of all chronic HCV infections in the United States-without prior ascertainment of HCV risk.

The proposed pathogenesis of autoimmune hepatitis involves the combination of genetic predisposition and environmental triggers. The genetic predisposition may relate to several defects in immunologic control of autoreactivity. An environmental agent triggers the autoimmune response against liver antigens, causing necroinflammatory liver damage, fibrosis, and, eventually, cirrhosis, if left untreated [4].

Genetic susceptibility to developing autoimmune hepatitis has been associated with the HLA haplotypes B8; B14, DR3, DR4, and Dw3. C4A gene deletions are associated with the development of autoimmune hepatitis in younger patients [5]. HLA-DR3-positive patients are more likely than other patients to have aggressive disease, which is less responsive to medical therapy and more often results in liver transplantation; in addition, these patients are younger than other patients at the time of their initial presentation. HLA-DR4-positive patients are more likely to develop extrahepatic manifestations of their disease [6]. Among the several viruses implicated as triggering agents are rubella, Epstein-Barr, and hepatitis A, B, and C. Some authors have shown a high amino acid sequence homology between hepatitis $C$ virus (HCV) polyprotein and CYP2D6, the molecular target of Liver-Kidney Microsomal type 1 (LKM-1) antibody, which suggests that molecular mimicry, may trigger production of LKM-1 antibody in HCV infection [7]. Current evidence suggests that liver injury in a patient with autoimmune hepatitis is the result of a cell-mediated immunologic attack. Aberrant display of Human Leukocyte Antigen (HLA) class II on the surface of hepatocytes facilitates the exposure of normal liver cell

*Corresponding author: Mona Gamal Morsi, Medical Microbiology \&Immunology, Alexandria Faculty of Medicine, Egypt, Tel: 01005171621; E-mail: morsirg@yahoo.com

Received April 15, 2013; Accepted June 21, 2013; Published July 01, 2013

Citation: Shalaa AY, Harfoush RA, Ahmed MA, ElKhouly EH, Morsi MG (2013) Genetic Basis of Chronic Hepatitis C Virus and Autoimmune Hepatitis: A Comparative Study. J Medical Microbiol Diagnosis S1: 004. doi:10.4172/21610703.S1-004

Copyright: @ 2013 Shalaa AY, et al. This is an open-access article distributed under the terms of the Creative Commons Attribution License, which permits unrestricted use, distribution, and reproduction in any medium, provided the original author and source are credited. 
membrane constituents to Antigen-Presenting Cells (APCs) [8]. The reasons for the aberrant HLA display are unclear. It may be initiated or triggered by genetic factors, viral infections (e.g., acute hepatitis A or B, Epstein-Barr virus infection), and chemical agents (e.g., interferon, melatonin, alpha methyldopa, oxyphenisatin, nitrofurantoin, tienilic acid) [9]. As the etiology of autoimmune hepatitis is unknown. Several factors (e.g., viral infection, drugs, environmental agents, genetic factors) may trigger an autoimmune response and autoimmune disease. So, the current study will illustrate some genetic (HLA alleles) associated with clinical course and outcome of HCV and autoimmune hepatitis aiming at successful therapy of both conditions.

\section{Subjects and Methods}

Eighty adult patients with abnormal liver function tests ( 40 chronic $\mathrm{HCV}$ and 40 autoimmune hepatitis free of $\mathrm{HBV}$ and $\mathrm{HCV}$ ) were enrolled in the current study selected from Tropical department of Alexandria Main University Hospital and Alexandria Armed Forces Hospital as well as 20 age and sex matched healthy controls. Exclusion criteria were cardiac, renal, diabetic, hypertensive and HIV positive cases. Their ages ranged (16-64 years) with a mean of ( $38 \pm 12.5$ years). Twenty unrelated healthy controls chosen from health care workers were included in the current study. All subjects (cases and controls; 100 in number) were 36 males (36\%) and 64 females (64\%). An informed consent was taken from all enrollees before sampling. Investigations done to all enrollees were; full history taking, clinical examination and the following laboratory tests [10-12] i. Complete blood picture using an automated cell counter (sysmex (KX-21 N), Roche, Japan), ii. Liver function tests (ALT, AST, bilirubin, albumin, alkaline phosphatase and gamma glutamyl transferase using Dimension RxL (Dad Behring Germany). iii. Detection of HBsAg, HBe Ag, HBc IgM by ELISA (Behring), and HCV $\mathrm{Ab}$ using (Ortho $3^{\text {rd }}$ generation ELISA,USA) technique. iv. Detection and quantitation of HCV RNA by Real Time Polymerase Chain Reaction (RT- PCR). v. Genotyping of HCV by line probe assay INNOLiPA (Innogenetics, USA)-Detection and semiquantitation of ANA, ASMA, AMA, AL/KM and p-ANCA auto-antibodies using Immuglo auto-antibody test system (Immco diagnostics, USA) by indirect immunofluorescent technique (IF). While anticardiolipin (ACA) was done by commercial Enzyme Linked Immunosorbant Assay (ELISA). Patients sera were incubated in mouse kidney/stomach/liver substrate sections for (ANA, ASMA, and AMA) and on human neutrophil substrate for p-ANCA to allow binding of antibodies to substrate. Any antibody not bound was removed by rinsing the slide. Bound antibodies of IgG class were detected by incubation of substrate with fluorescein with substrate labelled-antihuman IgG conjugate. The reactions were observed under fluorescent microscopy and presence of autoantibodies was demonstrated by an apple green fluorescence of specific structure in sera of patients. The titer was determined by testing serial dilutions and $<20$ was reported as a negative result. 6 -HLA class II $(D R B 1 * 01 *$ DRB $1 * 15)$ typing: genomic DNA was extracted from whole blood (after lysis by lysing buffer) using Qiagen spin column QIA amp ${ }^{\circledR}$ DNA Blood Mini Kit. HLA classII alleles were determined at the genotype level with 2digit intermediate/low resolution. This was performed using INNO-LiPA plus; a line probe assay designed for molecular typing of HLA alleles at the allele group level. The principle of the test was based on the reverse hybridization of the amplified biotinylated DNA sample which was chemically denatured, and the separated strands were hybridized with specific oligonucleotide probes immobilized as parallel lines on membrane-based strips. This was followed by a stringent wash step to remove any mismatched amplified material. After the stringent wash, streptavidin conjugate with alkaline phosphatase was added and bound to any biotinylated hybrid previously formed. Incubation with a substrate solution containing a chromogen resuted in a purple/brown precipitate. The reaction was stopped by a wash step, and the reactivity pattern of the probe was recorded. An amplification kit (INNO-LiPA HLA A*1-8 and DRB1*-15 amp Plus) was provided for standardized preparation of biotinylated amplified samples. The amplification kit was based on polymerase chain reaction (PCR). Amplification products were subsequently hybridized using 1 typing strip on which 37 sequencespecific DNA probes and 2 control probes were fixed. The INNO-LiPA HLA plus was designed to give the best possible resolution, at the allele group (this means the first 2 digits after the asterisk in an allele name when following standard HLA nomenclature e.g. HLA-DR1*01.

\section{Data Analysis}

Descriptive statistics included range, mean $\pm \mathrm{SD}$, median, frequencies (number of cases) and percentages when appropriate. Comparisons of numerical variables between the study groups were made using the Mann Whitney $U$ test for independent samples. To compare categorical data, the Chi squared $\left(\chi^{2}\right)$ test was used. When the expected frequency was less than 5, Fisher Exact test was used instead. Accuracy was represented using the terms sensitivity and specificity. Receiver operator characteristic analysis was used to determine the optimum cut off value for the studied tests. Various variables were tested for correlation using the Spearman rank correlation coeffeicient equation for non-normal variables $(r) . P$ values less than 0.05 were considered statistically significant. Normality of data was checked by the Kolmogorov Smirnov test. Our methods violated the normal assumption; therefore, the data were analyzed using non-parametric tests. Two-tailed tests were used where appropriate. All statistical calculations were performed using the computer programs Microsoft Excel 2007 (Microsoft Corporation, NY, and United States) and SPSS (Statistical Package for the Social Sciences; SPSS Inc., USA) version 15 for Microsoft Windows.

\section{Results}

In Table 1, comparing the different groups according to HCV RNA

\begin{tabular}{|c|c|c|c|}
\hline & $\begin{array}{l}\text { Chronic HCV } \\
(n=20)\end{array}$ & $\begin{array}{l}\text { Cirrhotics } \\
(n=20)\end{array}$ & Test of sig. \\
\hline \multicolumn{4}{|l|}{ HCV RNA $\times 10^{4}$} \\
\hline Min.-Max. & $2.14-160.0$ & $16.31-1528.10$ & \multirow[t]{3}{*}{${ }^{k W} p=0.008^{*}$} \\
\hline Mean \pm SD & $51.01 \pm 47.85$ & $251.72 \pm 43.85$ & \\
\hline Median & 38.50 & 83.36 & \\
\hline${ }^{\mathrm{MW}} \mathrm{p}_{1}$ & & $0.003^{*}$ & \\
\hline${ }^{m w} p_{2}$ & & & \\
\hline
\end{tabular}

$p: p$ value for comparing between the different studied groups

$p 1$ : $p$ value for comparing between control with each other group

$\mathrm{p} 2$ : $\mathrm{p}$ value for comparing between $\mathrm{Ch}$. Hepatitis with each other group

$\mathrm{KW}$ : for Kruskal Wallis test

MW: for Mann Whitney test

*: Statistically significant at $p \leq 0.05$

Table 1: HCV RNA levels among Chronic HCV cases group I.

\begin{tabular}{|c|c|c|c|c|c|c|}
\hline \multirow[t]{2}{*}{ HCV viral load (IU/ml) } & \multicolumn{2}{|c|}{$\begin{array}{l}\text { Chronic HCV } \\
(n=20)\end{array}$} & \multicolumn{2}{|c|}{$\begin{array}{l}\text { Cirrhotics } \\
(n=20)\end{array}$} & \multicolumn{2}{|c|}{ Total $(n=40)$} \\
\hline & No & $\%$ & No & $\%$ & No & $\%$ \\
\hline Very low $\left(<10^{4}\right)$ & 0 & 0.0 & 0 & 0.0 & 0 & 0.0 \\
\hline $\operatorname{Low}\left(10^{4}-10^{5}\right)$ & 6 & 30.0 & 0 & 0.0 & 8 & 13.3 \\
\hline Moderate $\left(10^{5}-10^{6}\right)$ & 12 & 60.0 & 12 & 60.0 & 36 & 60.0 \\
\hline High $\left(10^{6}-10^{7}\right)$ & 2 & 10.0 & 6 & 30.0 & 14 & 23.3 \\
\hline Very high $\left(>10^{7}\right)$ & 0 & 0.0 & 2 & 10.0 & 2 & 3.3 \\
\hline
\end{tabular}

Table 2: HCV viral load among chronic HCV cases (group I). 


\begin{tabular}{|c|c|c|c|c|c|}
\hline Variables tested & $\begin{array}{l}\text { Frequency } \\
\%\end{array}$ & $\begin{array}{l}\text { Sensitivity } \\
\%\end{array}$ & $\begin{array}{l}\text { Specificity } \\
\%\end{array}$ & Positive predictive value $\%$ & Negative predictive value $\%$ \\
\hline ANA & 45 & 48.6 & 95.7 & 94.7 & 53.7 \\
\hline ASMA & 47.5 & 51.4 & 87 & 86.4 & 52.6 \\
\hline AMA & 2.5 & 2.7 & 100 & 100 & 39 \\
\hline AL/KM & 7.5 & 8.1 & 100 & 100 & 40.4 \\
\hline p-ANCA & 52.5 & 56.8 & 100 & 100 & 59 \\
\hline ACA & 17.5 & 18.9 & 75.4 & 76.6 & 30.2 \\
\hline $\begin{array}{l}\text { Complete profile of } \\
\text { autoantibodies }\end{array}$ & & 0 & 1.4 & 5.1 & 100 \\
\hline
\end{tabular}

ANA: Anti-nuclear antibodies.

AMA: Anti-mitochondrial antibody.

AL/KM: Anti-liver kidney microsomal antibody.
ASMA: Anti-smooth muscle antibody.

pANCA: Perinuclear anti-neutrophil cytoplasmic antibody

ACA: Anticardiolipin antibody

Table 3: Test performance among patients with suspected autoimmune hepatitis (grouplI).

\begin{tabular}{|c|c|c|c|c|}
\hline HLA alleles & $\begin{array}{l}\text { Chronic HCV } \\
(n=40) \\
\text { No. }(\%)\end{array}$ & $\begin{array}{l}\text { Autoimmune } \\
\text { hepatitis } \\
(n=40) \text { No. }(\%)\end{array}$ & $\begin{array}{l}\text { Controls } \\
(n=20) \\
\text { No. }(\%)\end{array}$ & $\begin{array}{l}\text { P of Fisher } \\
\text { exact test }\end{array}$ \\
\hline HLA A1 & $40(100 \%)$ & $6(13 \%)$ & $20(100 \%)$ & $0.003^{*}$ \\
\hline HLA A6 & $20(50 \%)$ & $34(90 \%)$ & $15(75 \%)$ & $0.002^{*}$ \\
\hline HLA A8 & $20(50 \%)$ & $40(100 \%)$ & $5(25 \%)$ & $0.003^{*}$ \\
\hline HLA DRB1* 01 & $1(2.5 \%)$ & $1(2.5 \%)$ & $6(38.5 \%)$ & 0.324 \\
\hline HLA DRB1* 02 & $1(2.5 \%)$ & $1(2.5 \%)$ & $10(50 \%)$ & 0.456 \\
\hline HLA DRB1* 03 & $1(2.5 \%)$ & $28(70 \%)$ & $8(40 \%)$ & $0.005^{\star}$ \\
\hline HLA DRB1* 04 & $1(2.5 \%)$ & $7(17.5 \%)$ & $12(60 \%)$ & $0.005^{\star}$ \\
\hline HLA DRB1* 05 & $1(2.5 \%)$ & $26(65 \%)$ & $1(5 \%)$ & $0.003^{*}$ \\
\hline HLA DRB1* 06 & $0(0 \%)$ & $1(2.5 \%)$ & $1(5 \%)$ & 0.800 \\
\hline HLA DRB1* 07 & $24(60 \%)$ & $0(0 \%)$ & $0(0 \%)$ & $0.004^{*}$ \\
\hline HLA DRB1* 08 & $4(10 \%)$ & $1(2.5 \%)$ & $1(5 \%)$ & 0.732 \\
\hline HLA DRB1* 09 & $8(20 \%)$ & $1(2.5 \%)$ & $1(5 \%)$ & 0.160 \\
\hline HLA DRB1* 10 & $9(22.5 \%)$ & $1(2.5 \%)$ & $0(0 \%)$ & 0.345 \\
\hline HLA DRB1* 11 & $16(40 \%)$ & $0(0 \%)$ & $0(0 \%)$ & $0.005^{\star}$ \\
\hline HLA DRB1* 12 & $2(8 \%)$ & $1(2.5 \%)$ & $0(0 \%)$ & 0.123 \\
\hline HLA DRB1* 13 & $5(9.5 \%)$ & $1(2.5 \%)$ & $0(0 \%)$ & 0.234 \\
\hline HLA DRB1* 14 & $2(8 \%)$ & $1(2.5 \%)$ & $0(0 \%)$ & 0.546 \\
\hline HLA DRB1* 15 & $5(9.5 \%)$ & $0(0 \%)$ & $0(0 \%)$ & 0.675 \\
\hline
\end{tabular}

Table 4: Frequency of HLA-A1, A6, A8 \& DRB*1-15 alleles among chronic HCV (groupl), Autoimmune hepatitis (grouplI) and controls (grouplII).

levels, it was statistically significant $\left({ }^{\mathrm{KW}} \mathrm{p}=0.008\right)$.

Table 2 illustrates HCV viral load among chronic HCV cases (group I). According to total cases (40 chronic HCV; 20 with and 20 without cirrhosis), (13\%) were low viremia, (60\%) were moderate, $(23.3 \%)$ were high and only $(3.3 \%)$ were presenting with very high HCV RNA viral load.

According to results of autoantibody test system, patients with autoimmune hepatitis (AIH no. 40) group II were at least giving a positive high titer with one of these sero markers. Table 3 shows the sensitivity of ANA, ASMA, AMA, AL/KM, p-ANCA and ACA was $48.6 \%, 51.4 \%, 2.7 \%, 8.1 \%, 56.8 \%$ and $18.9 \%$ respectively with high specificity( $100 \%$ for all antibodies except for ANA 95.7\%, ASMA $87 \%$ and ACA $75.4 \%$. However, using a complete profile of autoantibodies increased the overall sensitivity to $100 \%$ and specificity to $91.4 \%$. Table 4 shows the frequency of HLA-A1, A6, and A8 \& DRB*1-15 alleles among chronic HCV (group I), autoimmune hepatitis (group II) and controls (group III).

\section{Discussion}

Autoimmune hepatitis (AIH) is an unresolving hepatocellular inflammation of unknown cause that is characterized by presence of

periportal hepatitis on histologic examination, tissue antibodies in serum and hypergammaglobulinemia [13]. In the current study the sensitivity of ANA, ASMA, AMA, AL/KM, p-ANCA and ACA was $48.6 \%, 51.4 \%, 2.7 \%, 8.1 \%, 56.8 \%$ and $18.9 \%$ respectively with high specificity (100\% for all antibodies except for ANA 95.7\%, ASMA $87 \%$ and ACA 75.4\%). However, using a complete profile of autoantibodies increased the overall sensitivity to $100 \%$ and specificity to $91.4 \%$. These findings were in agreement with [14]. They postulated that simultaneous presence of more than one antibody increased the probability of AIH diagnosis [14]. Other investigators reported high specificity (100\%) and $81 \%$ sensitivity among their AIH cases [15]. Furthermore, other researchers found that these autoantibodies could be used as useful prognostic markers [16].

The mechanism of autoimmunity is not fully understood but may involve binding of antigenic peptides to human leucocyte antigen (HLA) [17]. Several researchers have tried to establish a relationship between HLA class I \& II and chronic hepatitis either by HCV or autoimmune mechanism however, the results were inconsistent. With the development of polymerase chain reaction (PCR), the identification of HLA alleles at the DNA level had allowed more precise determination of susceptible epitopes showing a strong association with various viral and autoimmune hepatitis [18].

In the present study HLA $\mathrm{A} 1, \mathrm{DRB} 1 * 07, \mathrm{DRB} 1 * 11$ were highly associated with chronic HCV cases ( $\mathrm{p}<0.003 *, 0.004 *, 0.005$ respectively compared to controls. While $\mathrm{DRB} 1 * 03, \mathrm{DRB} 1^{*} 04$ controls were not infected with $\mathrm{HCV}$, denoting that these may be protective alleles against HCV infection. These findings were in accordance with others done elsewhere who claimed that $\mathrm{DRB} 1 * 07$ is the allele associated with persistence of HCV and non response to Interferon, while HLADR*11 was associated with self limiting and spontaneous clearance of the virus [2,19-22]. Among our autoimmune hepatitis cases HLAA6, A8 and DRB1*03 and DRB $1 * 05$ were the predominant alleles $(\mathrm{p}<0.002 *, 0.003 *, 0.005 *, 0.003 *)$ respectively. Researches done allover the world reported similar findings $[3,6,19]$.

We can conclude that certain HLA alleles of class I or and II could be associated with both hepatitis (either caused by HCV or autoimmune) and can predict clinical course and outcome of the disease. Also, our findings could help clinicians in selecting proper regimen as early as possible saving money and complications of wrong medications.

\section{Acknowledgment}

We would like to acknowledge Alexandria Main Armed Forces Hospital and Alexandria Faculty of Medicine, Egypt who sponsored materials and equipment used in our current study. 
Citation: Shalaa AY, Harfoush RA, Ahmed MA, ElKhouly EH, Morsi MG (2013) Genetic Basis of Chronic Hepatitis C Virus and Autoimmune Hepatitis: A Comparative Study. J Medical Microbiol Diagnosis S1: 004. doi:10.4172/2161-0703.S1-004

Page 4 of 4

\section{References}

1. Flamm SL (2003) Chronic hepatitis C virus infection. JAMA 289: 2413-2417.

2. Trapero-Marugan M, Moreno-Monteagudo JA, Garcia-Buey L, Borque MJ, Medina J, et al. (2007) Clinical and pathological characteristics and response to combination therapy of genotype 4 chronic hepatitis $C$ patients: experience from a spanish center. J Chemother 19: 423-427.

3. Manns MP, Vogel A (2006) Autoimmune hepatitis, from mechanisms to therapy. Hepatology 43: S132-144.

4. Badiani RG, Becker V, Perez RM, Matos CA, Lemos LB, et al. (2010) Is autoimmune hepatitis a frequent finding among $\mathrm{HCV}$ patients with intense interface hepatitis? World J Gastroenterol 16: 3704-3708.

5. Mayo MJ (2003) Extrahepatic manifestations of hepatitis C infection. Am J Med Sci 325: 135-148.

6. OstojiÄ $\mathrm{R}$ (2003) Autoimmune hepatitis. Acta Med Croatica 57: 201-205

7. Vento S, Cainelli $F(2004)$ Is there a role for viruses in triggering autoimmune hepatitis? Autoimmun Rev 3: 61-69.

8. García-Carrasco M, Escárcega RO (2006) Extrahepatic autoimmune manifestations of chronic hepatitis C virus infection. Ann Hepatol 5: 161-163.

9. Ramos-Casals M, Cervera R, Lagrutta M, Medina F, García-Carrasco M, et al. (2004) Clinical features related to antiphospholipid syndrome in patients with chronic viral infections (hepatitis C virus/HIV infection): description of 82 cases. Clin Infect Dis 38: 1009-1016.

10. Boffeys. Molecular Biology techniques (1986) In: Wilson K, Goulding KH. A Biologist's Guide to Principles and Techniques of Practical Biochemistry (3 ed) Edward Arnold, Great Britain

11. Burrin $D H$ (1986) Immunochemical technique. In: Wilson K, Goulding KH (eds.). A Biologist's Guide to Principles and Techniques of Practical Biochemistry (3 ed) Edward Arnold Great Britain.

12. Terjung B, Bogsch F, Klein R, Söhne J, Reichel C, et al. (2004) Diagnostic accuracy of atypical p-ANCA in autoimmune hepatitis using ROC- and multivariate regression analysis. Eur J Med Res 9: 439-448.

13. Ostoji Äł R (2003) [Autoimmune hepatitis]. Acta Med Croatica 57: 201-205.

14. Bakker-Jonges LE, ter Borg PC, van Buuren HR, Hooijkaas H (2006) [A retrospective study on the role of antibodies against soluble liver antigen (antiSLA antibodies) and other autoantibodies in the diagnostics of autoimmune hepatitis]. Ned Tijdschr Geneeskd 150: 490-494.

15. Strassburg CP, Manns MP (2002) Autoantibodies and autoantigens in autoimmune hepatitis. Semin Liver Dis 22: 339-352.

16. Czaja AJ, Shums Z, Norman GL (2004) Nonstandard antibodies as prognostic markers in autoimmune hepatitis. Autoimmunity 37: 195-201.

17. Möller E (1998) Mechanisms for induction of autoimmunity in humans. Acta Paediatr Suppl 424: 16-20.

18. Bowditch RD, Tani P, Fong KC, McMillan R (1996) Characterization of autoantigenic epitopes on platelet glycoprotein Ilb/lla using random peptide libraries. Blood 88: 4579-4584.

19. Yee LJ (2004) Host genetic determinants in hepatitis C virus infection. Genes Immun 5: 237-245.

20. Scotto G, Fazio V, D’Alessandro G, Monno L, Saracino A, et al. (2003) Association between HLA class II antigens and hepatitis $\mathrm{C}$ virus infection. J Bio Regul Homeost Agents 17: 316-321.

21. Thio CL, Thomas DL, Goedert JJ, Vlahov D, Nelson KE, et al. (2001) Racia differences in HLA class II associations with hepatitis C virus outcomes. J Infect Dis 184: 16-21.

22. Wolf DC, Raghuraman UV, Katz J (2012) Autoimmune hepatitis, Workup (Medline).
This article was originally published in a special issue, Bacterial Pathogenecity \& Epidemiology handled by Editor. Dr. Morabito Stefano, National Institute of Health, Italy 